\title{
A REGULAÇÃO DAS ASTREINTES NO CÓDIGO DE PROCESSO CIVIL E NO CÓDIGO DE DEFESA DO CONSUMIDOR: EFEITOS SOBRE A EFICÁCIA DAS AÇÕES PARA A TUTELA DAS OBRIGAÇÕES ESPECÍFICAS EM DEMANDAS DE CONSUMO
}

\section{Camille da Silva Azevedo Ataíde ${ }^{1}$ Dennis Verbicaro Soares ${ }^{2}$}

Resumo: O presente artigo, através do método dedutivo e por meio de pesquisa bibliográfica nacional e estrangeira, tem por escopo analisar relevantes aspectos sobre a regulação da multa cominatória prevista nos artigos 537 do CPC e 84 do CDC, também denominada astreintes, delineada para conferir maior efetividade às decisões judiciais que contenham em seu bojo obrigações de fazer, não fazer e entregar coisa. O sucessivo regramento do instituto pelas leis processuais gerais tem suscitado dúvidas e resultado em aplicações divergentes pelo Judiciário, não raro impactando negativamente o compromisso assumido com a efetividade da tutela jurisdicional nas relações de consumo.

Palavras-chaves: Astreintes. Tutela das Obrigações Específicas. Código de Processo Civil. Código de Defesa do Consumidor. Relações de Consumo.

\section{THE REGULATION OF PROCEDURAL FINE IN THE CIVIL PROCEDURE CODE AND THE CONSUMER DEFENSE CODE: EFFECTS ON THE EFFECTIVENESS OF THE SPECIFIC OBLIGATIONS ACTIONS IN CONSUMER DEMANDS}

\begin{abstract}
This article, through the deductive method and through national and foreign bibliographic research, has the purpose of analyzing relevant aspects on the regulation of the procedural fine foreseen in articles 537 of the CPC and 84 of the CDC, also denominated astreintes, designed to give greater effectiveness To judicial decisions that contain in their bulge obligations to do, not do and deliver thing. The successive regulation of the institute by general procedural laws has raised doubts and results in divergent applications by the Judiciary, often negatively impacting the commitment made to the effectiveness of judicial protection in consumer relations.
\end{abstract}

Keywords: Astreintes. Specific Obligations Actions. Code of Civil Procedure. Code of Consumer Protection. Consumer Relations.

\footnotetext{
${ }^{1}$ Mestranda no Programa de Pós-Graduação em Direito da Universidade Federal do Pará, na linha de pesquisa Constitucionalismo, Democracia e Direitos Humanos. Pesquisadora do grupo de pesquisa Consumo e Cidadania (CNPq). Especialista em Direito Civil e Processual Civil pela Fundação Getúlio Vargas - Direito Rio. Advogada. E-mail: camille.ataide@ hotmail.com

${ }^{2}$ Doutor em Direito do Consumidor pela Universidade de Salamanca (Espanha). Mestre em Direito do Consumidor pela Universidade Federal do Pará. Professor da Graduação e do Programa de Pós-Graduação Stricto Sensu da Universidade Federal do Pará-UFPA, Professor da Graduação e Especialização do Centro Universitário do ParáCESUPA, Professor da Pós-Graduação Lato Sensu em Direito do Consumidor da Universidade Federal do Rio Grande do Sul-UFRGS, além de ministrar aulas e seminários em outras instituições de ensino superior, bem como nas Escolas Superiores da Magistratura (ESM) e da Advocacia (ESA). É Editor-Chefe da Revista Amazônica de Direito Journal of Law, Procurador do Estado do Pará e Advogado. E-mail: dennisverbicaro@ bol.com.br
}

Revista de Direito, Globalização e Responsabilidade nas Relações de Consumo | e-ISSN: 2526-0030 | Maranhão | v. 3 | n. 2 | p. 82 - 102 | Jul/Dez. 2017 


\section{INTRODUÇÃO}

O artigo 84 do Código de Defesa do Consumidor inaugurou o reconhecimento das obrigações de fazer e não fazer como uma nova modalidade de ação executiva lato sensu no ordenamento jurídico brasileiro tendo, posteriormente, condicionado a reforma do CPC/73, através da Lei 8.952, de 13 de dezembro de 1994, para estender esta inovação a todas as demandas submetidas à lei processual geral, por meio do artigo 461.

A sistemática introduzida pelos supracitados dispositivos destacou-se não apenas por ter conferido normatividade ao princípio da primazia pelo cumprimento específico (in natura) das obrigações, mas, especialmente, por ter disponibilizado ao magistrado instrumentos capazes de realizar o direito material declarado no provimento, tais como medidas de urgência, de constrição patrimonial e dissuasórias, resultando em um modelo de processo sincrético, em que a fase executiva tornou-se extensão do trânsito em julgado da decisão, contribuindo para a efetividade e celeridade da prestação jurisdicional.

O novo paradigma inaugurado foi delineado para obstar condutas protelatórias no cumprimento do comando judicial pelo réu e consagrar um legítimo "processo de resultados". A tutela executiva lato senso, desde então, tem assumido importância ímpar na proteção do consumidor, individual e coletivamente considerado.

No entanto, as assimilações posteriores do microssistema previsto no art. 84 do CDC pelo art. 461 do CPC/73 e, agora, pelo art. 537 do Lei 13.105/2015, têm gerado grandes preocupações nos agentes que atuam na defesa do consumidor. Em que pese aquele microssistema possuir autonomia normativa para impor suas determinações às demandas de consumo, os magistrados pautam suas decisões no regramento geral do CPC, em razão dos pormenores deste Código, olvidando-se, por vezes, das especificidades inerentes à relação de consumo.

O objetivo geral da presente pesquisa é descrever e analisar criticamente o panorama da atual regulação da multa no Código de Processo Civil, tendo como referência seu impacto nas demandas de consumo. Como objetivo específico, far-se-á o cotejo entre as construções doutrinárias e jurisprudenciais em torno da regulação da multa no Código de Processo Civil de 1973 e as disposições do Código vigente para que seja possível aferir em que medida o novo estatuto processual avançou, ou recuou, em termos de tutela das obrigações específicas. A justificativa para a pesquisa deve-se ao fato de que as controvérsias e lacunas em torno da 


\section{A REGULAÇÃO DAS ASTREINTES NO CÓDIGO DE PROCESSO CIVIL E NO CÓDIGO DE DEFESA \\ DO CONSUMIDOR: EFEITOS SOBRE A EFICÁCIA DAS AÇÕES PARA A TUTELA DAS \\ OBRIGAÇÕES ESPECÍFICAS EM DEMANDAS DE CONSUMO}

disciplina da multa bem como a sua interpretação aquém das exigências necessária à tutela do consumidor comprometem o seu potencial coercitivo e a efetividade da tutela jurisdicional.

Quanto à metodologia de pesquisa, utilizou-se a pesquisa exploratória e bibliográfica em livros especializados no tema. Utilizou-se, também, pesquisa jurisprudencial para demonstrar a divergência de entendimento entre os órgãos jurisdicionais, bem como o métodu de interpretação dedutivo, sistemático e teleológico.

\section{A EVOLUÇÃO DA JURISDIÇÃO E DO PROCESSO CIVIL SOB A PERSPECTIVA DA EFETIVIDADE DA TUTELA JURISDICIONAL}

No sistema processual Brasileiro, a busca pela atribuição de maior efetividade à prestação da tutela jurisdicional intensificou-se nos últimos 25 anos, período de relevantes reformas nas leis de conteúdo processual e que inclusive culminou no advento de um novo Código de Processo Civil, Lei $n^{\circ} 13.105 / 2015$, a partir da consolidação dos novos valores assumidos pela Jurisdição no Estado Contemporâneo, notadamente o valor da instrumentalidade e da efetividade.

Com efeito, pode-se apontar a garantia da inafastabilidade do controle jurisdicional, prevista no art. $5^{\circ}, \mathrm{XXXV}$ da Constituição de 1988 , como ponto de partida ao alcance de maiores resultados ao sistema processual, sendo alvo de laboriosas construções doutrinárias que chegam a identificá-la como a garantia de acesso à justiça, conformando a atuação do legislativo e do judiciário. Assim, deve o legislador elaborar normas e técnicas jurídicas que favoreçam o pleito do titular de uma posição jurídica de vantagem junto aos órgãos do judiciário, não sendo suficiente a disponibilização de diferentes ações judiciais, mas que tais ações sejam conformadas às exigências do direito material e às peculiaridades das partes envolvidas.

O Judiciário, por sua vez, deve tutelar materialmente as legítimas pretensões jurídicas lesadas ou ameaças postas a sua apreciação, utilizando-se de instrumentos processuais aptos a conceder proteção efetiva e adequada ao direito de quem lhe bate às portas. Por efetividade e adequação da prestação jurisdicional, entende-se como a capacidade do processo de produzir os resultados práticos que dele são naturalmente esperados, exigindo-se que ao resultado formal (i.e: decisões e sentenças), acrescente-se a aptidão para produzir efeitos concretos e em tempo hábil. 
Aquele novo paradigma levou o legislador à inclusão do art. 84 ao Código de Defesa do Consumidor, Lei $\mathrm{n}^{\mathrm{o}}$ 8.078/90, inaugurando novas espécies de provimentos jurisdicionais referentes à tutela das obrigações específicas de fazer ou não fazer. O dispositivo, além de declarar a primazia pela maior coincidência possível entre a prestação devida e a tutela jurisdicional entregue ${ }^{3}$, autoriza o juiz a determinar medidas de urgência, de constrição patrimonial e mesmo dissuasórias para que o réu não postergue sua submissão ao comando da decisão judicial.

Respondendo aos anseios dos consumidores que vinham experimentando violações sistematizadas em seus direitos, a tutela das obrigações específicas passou a ser largamente utilizada, dentre outras questões, para o controle das práticas empresariais abusivas, como na oferta e publicidade ilícitas, para a retirada do mercado de produtos e serviços danosos à vida, saúde e segurança e para a submissão forçada do fornecedor às obrigações legais e contratuais perante os consumidores, inclusive com a imposição de astreintes, medidas cautelares, uso da força policial e outros atos mais que conduzem à satisfação da obrigação original.

O Código de Defesa do Consumidor inovou o sistema processual quando introduziu o modelo sincrético de provimento jurisdicional para as obrigações específicas de fazer e não fazer, tornando-se fundamental para a proteção da grande maioria dos direitos básicos do consumidor previstos no art. $6^{\circ}$ do CDC. Diz-se sincrético o provimento porque congrega na decisão, ao mesmo tempo, cognição judicial acerca do direito e providências auto-executórias para garantir seu efetivo cumprimento, o que anos mais tarde levou à extinção da autonomia do processo de execução para os títulos executivos judiciais com a Lei n 11.232/05.

Nos parágrafos do art. 84 do CDC, há nítida ampliação dos poderes do magistrado, que poderá antecipar os efeitos da decisão por meio de antecipação de tutela $\left(\S 3^{\circ}\right)$, garantir o resultado útil da decisão antecipatória ou final por intermédio da multa coercitiva, astreintes $\left(\S 4^{\circ}\right)$, conceder medidas cautelares como busca e apreensão, determinar o impedimento de atividade nociva $\left(\S 5^{\circ}\right)$, havendo, inclusive, a possibilidade de conversão da obrigação específica inadimplida em perdas e danos, sem prejuízo da multa $\left(\S \S 1^{\circ}\right.$ e $\left.2^{\circ}\right)$.

\footnotetext{
${ }^{3}$ A primazia pelo cumprimento específico da obrigação está evidenciada no $\S 1^{\circ}$ do art. 84 do CDC ao estabelecer que a conversão da obrigação em perdas e danos somente será admissível se por elas optar o autor ou se impossível a tutela específica ou a obtenção do resultado prático correspondente. Segundo Eduardo Talamini (2003, p. 230) a "tutela específica" distingue-se da "obtenção de resultado prático equivalente" em razão daquela consistir na busca do "resultado final" através da própria conduta do demandado. A "especificidade", nesse caso, vai além do resultado final, abrangendo também o meio para a sua consecução, enquanto no "resultado prático equivalente" o resultado final (específico) é obtido através de terceiros.
} 


\section{A REGULAÇÃO DAS ASTREINTES NO CÓDIGO DE PROCESSO CIVIL E NO CÓDIGO DE DEFESA \\ DO CONSUMIDOR: EFEITOS SOBRE A EFICÁCIA DAS AÇÕES PARA A TUTELA DAS \\ OBRIGAÇÕES ESPECÍFICAS EM DEMANDAS DE CONSUMO}

A sistemática introduzida pelo Código do Consumidor foi posteriormente incluída e regulada de modo pormenorizado no art. 461 do Código de Processo Civil de 1973, através da Lei $n^{\circ} 8.952 / 1994$, mantendo praticamente a mesma redação do caput e parágrafos do art. $84^{4}$. Cabe ressaltar que a multa coercitiva reiterada no $\S 4^{\circ}$ do art. 461 representou uma das principais ferramentas para a realização de um legítimo "processo de resultados" nestes dois momentos legislativos, sem dúvida a medida mais utilizada por juízes e Tribunais ${ }^{5}$.

No entanto, na medida em que a multa coercitiva crescia em importância, muitas controvérsias surgiam em torno de sua aplicação, fomentada pela insuficiência de sua regulação paulatinamente evidenciava com a prática forense, o que afetou diretamente a eficácia esperada desta medida executiva e segurança jurídica. Durante muito tempo, a doutrina e a jurisprudência dos Tribunais Estatuais e Superiores revelavam interpretações diametralmente opostas, porém fundamentadas, a respeito de diversas questões atinentes à multa.

O art. 537 do vigente Código de Processo Civil de 2015 tratou mais minudentemente da multa, buscando "discipliná-la em atenção à construção doutrinária e jurisprudencial que se formou em torno dos $\S \S 4^{\circ}$ a $6^{\circ}$ do art. 461 do CPC de 1973, tomando, a propósito, partido em variadas questões" (SCARPINELLA, 2015, p. 369). Conforme se verá nos tópicos seguintes, lacunas e controvérsias ainda pairam sobre a regulação das astreintes no atual Código Processual, muitas das quais passíveis de soluções interpretativas razoáveis se levar-se em conta as especificidades das relações de consumo.

\section{ASTREINTES: NATUREZA JURÍDICA E CONCEITO}

Com relação à natureza jurídica da astreinte $^{6}$, identificada no $\mathrm{CPC} / 15$ simplesmente como "multa", predomina o entendimento de que a medida representa legítima técnica de tutela, em que pese existirem divergências pertinentes e que têm contribuído para a formação de modos

\footnotetext{
${ }^{4}$ Art. 84 da Lei ${ }^{\circ}$ 8.078/90: na ação que tenha por objeto o cumprimento da obrigação de fazer ou não fazer, o juiz concederá a tutela específica da obrigação ou determinará providências que assegurem o resultado prático equivalente ao do adimplemento. Art. 461 da Lei $n^{\circ}$ 5.869/73: na ação que tenha por objeto o cumprimento de obrigação de fazer ou não fazer, o juiz concederá a tutela específica da obrigação ou, se procedente o pedido, determinará providências que assegurem o resultado prático equivalente ao do adimplemento.

${ }^{5}$ Segundo Joaquim Spadoni (2001, p. 483), foi com o advento do art. 461 do CPC, veiculador das ações para a tutela específica das obrigações de fazer ou não fazer, que a utilização da multa como instrumento de atuação das decisões judiciais tomou maior relevo e funcionabilidade no âmbito jurídico.

${ }^{6}$ A astreinte é uma medida coercitiva de constrangimento indireto sobre o devedor, própria do direito francês, visando ao cumprimento da prestação imposta em decisão judicial. Teve origem e desenvolvimento na jurisprudência francesa ante a inexistência de dispositivo legal que a disciplinasse e representou uma espécie de reação contra o princípio consagrado de que ninguém poderia ser forçado a prestar fato pessoal.
} 
distintos de interpretar o momento de sua exigibilidade quando aplicada em provimentos de natureza provisória.

A corrente que entende ser a finalidade da multa assegurar a autoridade das decisões judiciais e, por conseguinte, manter a dignidade da justiça, defende a sua aplicação autônoma em relação ao direito declarado na decisão ${ }^{7}$. Sua função seria assegurar a imposição de uma ordem estatal $^{8}$. Tal entendimento repousa na concepção de que a atividade jurisdicional vai além de "dizer o direito", de decidir sobre a certeza ou não do direito alegado na demanda para alcançar o dever de impor suas próprias decisões através da ameaça de sanção patrimonial, independentemente do conteúdo e da possibilidade de reforma da decisão.

Logo, a incidência das astreintes representaria uma forma de punição pela violação da autoridade do juiz que, ao determinar uma conduta a ser cumprida pelo demandado, é simplesmente ignorada, levando ao descrédito a atividade jurisdicional perante a sociedade. Então, a multa teria incidência e seria exigível a partir do descumprimento da decisão judicial, afinal, segundo Spadoni (2001, p. 488) é a violação da obrigação processual derivada da relação Estado-Parte o fundamento da multa pecuniária, e não a obrigação de direito material.

Por outro lado, a corrente majoritária que considera a multa como técnica de tutela evidencia o caráter de acessoriedade em relação ao direito material. Assim, tanto o processo quanto as técnicas processuais são pensadas à luz das diferentes tutelas exigidas pelos direitos substanciais. Luiz Guilherme Marinoni (2010, p. 114) pondera que, se as tutelas dos direitos (necessidades no plano do direito material) são diversas, as técnicas processuais devem a elas se adaptar. Logo, o procedimento, a sentença e os meios executivos não seriam neutros ao direito material, não podendo ser pensados a sua distância.

Este entendimento permite a conclusão de que a decisão que fixa as astreintes constitui técnica de tutela, meio para o cumprimento efetivo da função jurisdicional. Então, sendo a multa aplicada em decisão judicial para assegurar o cumprimento, pelo réu, de determinada obrigação

\footnotetext{
${ }^{7}$ No Brasil, Sérgio Cruz Arenhart e Marcelo Lima Guerra são grandes defensores desta corrente.

${ }^{8}$ Os defensores desta corrente encontram no contempt of court tradicional ao sistema da common law suas premissas essenciais. As origens do contempt os court remontam ao direito inglês do início do século XII, no reinado de Henrique II (1154-1189). Considerando que o Rei não podia "tolerar um mau funcionamento da justiça em seu reino", necessitava-se de sua intervenção para "proibir que uma pessoa abusasse da situação que existia em termos de direito estrito (at law) ou exortá-la a comportar-se de acordo com a moral". Se não houvesse obediência à determinação, o indivíduo iria "meditar na prisão ou seus bens seriam objetos de sequestro, até que voltasse a ter seus melhores sentimentos" (DAVID, 1997, p. 7). Lima Guerra (1998) noticia que os poderes do Rei e da Chancelaria eram aptos a prestar tutela específica das obrigações em virtude de suas decisões vincularem diretamente a pessoa do réu sendo que, uma vez desobedecida a determinação, era considerado em contempt of court e mandado para a prisão até que decidisse cumprir o que determinava a decisão.
} 


\section{A REGULAÇÃO DAS ASTREINTES NO CÓDIGO DE PROCESSO CIVIL E NO CÓDIGO DE DEFESA \\ DO CONSUMIDOR: EFEITOS SOBRE A EFICÁCIA DAS AÇÕES PARA A TUTELA DAS \\ OBRIGAÇÕES ESPECÍFICAS EM DEMANDAS DE CONSUMO}

de fazer e sendo, posteriormente, tal decisão revogada, não haveria qualquer fundamento em cobrar o crédito resultante de sua incidência. Portanto, enquanto técnica processual de caráter acessório, a multa apenas será devida se a tutela jurisdicional permanecer devida ao autor.

É entendimento pacífico na jurisprudência e doutrina o caráter coercitivo ou coativo da multa. Com efeito, ela atua exercendo pressão psicológica sobre o réu, "forçando a vontade do sujeito - que eventualmente não pretende cumprir com o comando judicial - a comportar-se da forma esperada pelo Estado, desestimulando-o de adotar qualquer tipo de atitude" (ARENHART, 2008, p. 237).

A fixação das astreintes tem por finalidade estimular psicologicamente o réu a praticar um fazer ou não fazer, ou seja, cumprir a obrigação na forma específica. Esse estímulo apenas é possível com a ameaça de um mal grave que se sobreponha a qualquer vantagem auferida com o descumprimento da obrigação. Em razão disso, Arenhart (2008) conclui ser natural que a multa apresente certo aspecto de "violência", posto que sua função é precisamente essa: acenar com violência ao patrimônio do devedor recalcitrante, para forçá-lo a cumprir a decisão judicial.

Desse modo, pode-se afirmar que as astreintes correspondem a uma coação de caráter econômico porque influem no ânimo do devedor para que cumpra a prestação a qual se nega a cumprir a partir do receio em vir a sofrer severa redução patrimonial. Persistindo o inadimplemento, as astreintes alteram sua configuração de meio coercitivo para mera sanção patrimonial (MARINONI, 2010, p. 218).

No que tange ao conceito das astreintes, autores como Guilherme Rizzo Amaral (2010, p. 101) enfatizam a sua natureza de técnica de tutela acessória. Fabiano Carvalho (2004, p. 209) ressalta o viés psicológico pretendido pela multa. E Luiz Guilherme Marinoni (2010) destaca o desprovimento de finalidade sancionatória ou punitiva. Verifica-se, pela análise dos conceitos mais representativos fornecidos pela doutrina à multa, convergência quanto a vários aspectos, a saber: o seu caráter coercitivo, patrimonial, acessório, a independência em relação às perdas e danos e o desígnio para alcançar a tutela específica das obrigações.

\section{CABIMENTO DAS ASTREINTES}

Segundo o $\S 3^{\circ}$ do art. 84 do CDC, é lícito ao juiz conceder a tutela pleiteada liminarmente desde que relevante o fundamento da demanda e havendo justificado receio de ineficácia do provimento final. A natureza do provimento é antecipatória, ou seja, revela uma 
cognição sumária, porém relativamente exauriente, amparado na plausibilidade do direito e assumindo a decisão caráter satisfativo.

Com o advento do Código de Processo Civil de 2015, a ideia subjacente ao instituto da tutela antecipada subsiste sob a nomenclatura de tutela provisória. A tutela provisória, prevista no art. 294 do CPC, foi concebida pelo legislador para assegurar ou proteger um direito em situações de urgência ou casos de evidência, antes da decisão final, com base em uma compreensão ainda não concluída dos fatos, conferindo maior efetividade ao processo ao mesmo tempo em que atenua a crise de morosidade do judiciário.

A tutela de urgência será concedida quando houver elementos que evidenciem a probabilidade do direito e o perigo de dano ou o risco ao resultado útil do processo, nos termos do art. 300 do CPC. Observa-se, então, a similaridade dos fundamentos com aqueles autorizadores da tutela antecipada no art. $84, \S 3^{\circ}$ do CDC. No que tange à tutela de evidência, o fundamento é a probabilidade do direito e alguma das hipóteses do art. 311 do CPC $^{9}$, prescindindo da demonstração do perigo da demora.

Além de satisfativa, é possível que a concessão da tutela provisória (especificamente a fundamentada na urgência) assuma natureza cautelar ${ }^{10}$, portanto, protetiva, tendo por escopo preservar o direito do autor e não propriamente adiantar o pedido principal. Neste caso, embora inexista processo cautelar autônomo como outrora, é possível a veiculação de pedido de arresto, sequestro e demais medidas assecuratórias no processo principal, ou a concessão de outras medidas atípicas a partir do poder geral de cautela do juiz.

De modo mais objetivo do que o seu antecessor, o art. 537 do Código atual estabelece que a multa independe de requerimento da parte e poderá ser aplicada na fase de conhecimento, em tutela provisória ou na sentença, ou na fase de execução, desde que suficiente e compatível com a obrigação de fazer ou não fazer. Convém ressaltar que "obrigação" apresenta um conceito menos abrangente do que o de "dever", este entendido nas palavras de Talamini (2003, p. 126) como a "imposição jurídica da observância de determinado comportamento ativo ou omissivo, passível de ser resguardado por sanção".

Ao contrário do que prevê a literalidade dos artigos 536 e 537 do CPC, é pacífico o entendimento de que a tutela específica e, por conseguinte, a aplicação das astreintes, não está

\footnotetext{
${ }^{9}$ A respeito da tutela de evidência, existe controvérsia doutrinária sobre a taxatividade, ou não, do rol de possibilidades do art. 311 do CPC.

${ }^{10}$ Nos termos do parágrafo único do art. 294 do CPC, a tutela provisória de urgência, cautelar ou antecipada, pode ser concedida em caráter antecedente ou incidental.
} 


\section{A REGULAÇÃO DAS ASTREINTES NO CÓDIGO DE PROCESSO CIVIL E NO CÓDIGO DE DEFESA \\ DO CONSUMIDOR: EFEITOS SOBRE A EFICÁCIA DAS AÇÕES PARA A TUTELA DAS \\ OBRIGAÇÕES ESPECÍFICAS EM DEMANDAS DE CONSUMO}

restrita às obrigações contratuais, aplicando-se também a toda e qualquer conduta exigível por decorrência direta da lei, do dever legal. Aliás, o $§ 5^{\circ}$ do art. 536 do CPC autoriza a aplicação das astreintes para assegurar o cumprimento de sentença que reconheça deveres de natureza não obrigacional. Ainda, atualmente é pacífico o entendimento quanto ao cabimento da multa para assegurar o cumprimento de obrigações não apenas infungíveis ${ }^{11}$, mas também fungíveis, caracterizadas como aquelas que admitem adimplemento por ato de terceiro.

Em favorecimento da tutela das pretensões de consumo, especialmente aquelas que buscam satisfazer uma obrigação de reembolso dos fornecedores junto aos consumidores, o CPC/15 avançou nesta forma de tutela ao possibilitar a aplicação da multa para o cumprimento das obrigações de pagar $^{12}$, ainda que não explicitamente, diferentemente do CPC/73, que inadmitia esta possibilidade.

Conclui-se ser atribuição do juiz avaliar a conveniência da aplicação da multa ou qualquer medida sub-rogatória ${ }^{13}$ para o alcance dos objetivos processuais, seja em sede de conhecimento ou execução, podendo aplica-la em face das obrigações de fazer, não fazer, fungíveis ou infungíveis, de pagar quantia e entregar coisa, esta última autorizada pelo art. 538 do CPC.

\section{CRITÉRIOS E LIMITES AO VALOR DA MULTA}

A sistemática para a imposição da multa não deve ser aleatória, pois deverão ser observados parâmetros obrigatórios para que a mesma se torne exigível e não seja obstada nas instâncias subsequentes por aspectos formais ou utilitaristas, a saber: prazo razoável para cumprimento e valor suficiente e compatível com a obrigação, o que não se confunde com limitação do valor, sob pena de inafastável comprometimento da eficácia da técnica processual.

Quanto ao prazo razoável para o cumprimento da medida, deverá o juiz ponderar, dentre outros, aspectos como a urgência, a complexidade da obrigação e o custo financeiro, sendo a data da intimação do réu o termo inicial da contagem do prazo. Quanto à periodicidade

\footnotetext{
${ }^{11}$ O STJ consolidou este entendimento no julgamento do REsp 893.041/RS, Rel. Ministro Teori Albino Zavascki, Primeira Turma, julgado em 05.12.2006, Dj 14.12.2006.

${ }^{12}$ Art. 139. O juiz dirigirá o processo conforme as disposições deste Código, incumbindo-lhe: IV - determinar todas as medidas indutivas, coercitivas, mandamentais ou sub-rogatórias necessárias para assegurar o cumprimento de ordem judicial, inclusive nas ações que tenham por objeto prestação pecuniária.

${ }^{13}$ As medidas sub-rogatórias são mecanismos de cumprimento da ordem judicial que dispensam a colaboração do ordenado, haja vista que a prestação imposta pode ser atribuída a terceiro, de forma a realizar exatamente o resultado idêntico àquele que seria operado pelo devedor, a exemplo da medida de busca e apreensão.
} 
da multa, o CPC/15 impede maiores divergências ao não fixar um parâmetro específico, tal como o CDC o faz e o revogado $\mathrm{CPC} / 73$ fazia ao dispor sobre a "multa diária". Assim, é possível a incidência da multa em qualquer periodicidade diversa, inclusive em "horas", nos casos de urgência (TALAMINI, 2001).

Em relação ao valor da multa, este deverá ser compatível com a obrigação, ou seja, não poderá ser irrisório, sob pena de não fomentar a constrição patrimonial e psicológica do devedor, nem ser excessivamente elevado, o que poderá inviabilizar o cumprimento da obrigação principal e, eventualmente, a subsistência financeira do devedor.

Sobre a ideia de "suficiência" e "compatibilidade" da multa em relação à obrigação, Eduardo Talamini (2001, p. 243) leciona que não se trata de pura e simples limitação do valor da multa ao da obrigação, o que só faria sentido se aquela tivesse caráter indenizatório, havendo de estabelecer-se montante em patamar tal que concretamente influa no comportamento do demandado, o que diante das circunstâncias do caso - tal como a situação econômica do réu, sua capacidade de resistência, vantagens com o descumprimento, dentre outros - pode resultar em quantum que supere aquele referente ao valor atribuído ao bem jurídico visado.

O fato é que ainda persiste relevante controvérsia em relação à exigibilidade da multa quando seu valor ultrapassa o limite do benefício econômico pretendido com a ação.

São comuns os casos em que a sentença arbitra uma indenização de R \$-10.000,00, mas o valor da multa é cinco, dez, ou vinte vezes maior, tendo o Judiciário, na grande maioria das vezes, reduzido o valor para patamares irrisórios, que acabam por premiar a incúria e a resistência do réu, que prefere pagar a multa num valor simbólico a cumprir a obrigação específica objeto da ação, desacreditando o Judiciário e frustrando o consumidor, ambos igualmente prejudicados e desrespeitados com a contumácia do devedor.

Argumenta-se que por ter a multa caráter acessório, uma medida meramente garantidora do cumprimento da tutela, não poderia superar o valor da pretensão econômica, objeto da demanda e que, para evitar o suposto enriquecimento sem causa do consumidor, pode o juiz, de ofício, ou provocado pelo réu, diminuir o valor da multa cominatória a qualquer tempo, mesmo após o trânsito em julgado da decisão.

Ocorre que a multa do art. 84 do CDC é diferente de sua congenere prevista no art. 537 do CPC, em relação à natureza das partes processuais, pois, na primeira, teremos uma relação de consumo, enquanto que a segunda se aplicará a todas as demais relações processuais, 


\section{A REGULAÇÃO DAS ASTREINTES NO CÓDIGO DE PROCESSO CIVIL E NO CÓDIGO DE DEFESA \\ DO CONSUMIDOR: EFEITOS SOBRE A EFICÁCIA DAS AÇÕES PARA A TUTELA DAS \\ OBRIGAÇÕES ESPECÍFICAS EM DEMANDAS DE CONSUMO}

diferença essa sutil, mas não observada por muitos magistrados e que vem solapando a eficácia dissuasória da astreinte.

Aliás, a limitação da multa ao valor da obrigação não raro parte de uma comparação equivocada desta com a cláusula penal contida no art. 412 do Código Civil, a qual estabelece: "O valor da cominação imposta na cláusula penal não pode exceder o da obrigação principal". No entanto, a cláusula penal e a multa coercitiva, por possuírem natureza jurídica distintas, incidem regras jurídicas específicas, posto que a multa contida na primeira, seja moratória ou compensatória, é instituto de direito privado estipulada pelas próprias partes visando coibir abusos nas convenções particulares, enquanto que a segunda possui natureza processual e tem por escopo obrigar o réu ao cumprimento da decisão, garantindo a efetividade processual.

No julgamento do REsp 1.475.157/SC, em 18.09.2014, a $3^{\text {a }}$ Turma do STJ entendeu que a proporcionalidade da multa por descumprimento de decisão judicial deve ser avaliada em função da obrigação a que ela se refere. Assim, ao julgar recurso de uma instituição bancária num caso em que a obrigação principal era de $\mathrm{R} \$ 4.620$ e a multa, fixada em $\mathrm{R} \$-1.000,00$ por dia de atraso, chegou a R\$-237.000,00, o ministro relator Marco Aurélio Bellizze votou pela redução da multa diária para $\mathrm{R} \$-500,00$, entendendo que este valor era mais proporcional ao da obrigação principal, sem, contudo, alterar o número de dias em atraso.

Este posicionamento causa certa perplexidade. O Judiciário está abarrotado de causas em que o valor da obrigação é relativamente baixo, como no caso supracitado. Limitar o valor da multa ao da obrigação, nestes casos, retira consideravelmente o potencial coercitivo da medida, levando as empresas, como as grandes instituições bancárias, a descumprirem a determinação judicial após calcularem o custo-benefício da recalcitrância, repassando o encargo total devido aquando da execução, em alguma medida, ao preço final do produto disponível ao consumidor.

Aliás, a multa deve ser forte o suficiente para levar o devedor, se não a pagar a integralidade da condenação em uma única vez, ao menos tentar condições de pagamento mais favoráveis junto ao consumidor, quem detém o poder de barganha. Cumpre frisar que o juiz concede prazo razoável ao cumprimento da obrigação, a partir do qual só então passará a incidir a multa. Ou seja, o devedor não é surpreendido com a incidência repentina da multa, dispondo de tempo para planejar-se e cumprir a decisão, caso esteja de boa-fé.

É fundamental considerar que a violência sobre o patrimônio do devedor em razão da execução das astreintes regularmente incididas não é a finalidade principal de sua aplicação, 
pelo contrário, representa um aspecto acidental sinalizador do fracasso da medida coercitiva. Em sede doutrinária costuma-se realizar o interessante apontamento de que as astreintes surgiram para não serem cobradas haja vista que, se assim ocorrer, deve-se ao fato de terem fracassado enquanto medida coercitiva. Logo, não deve haver receio por parte dos juízes de fixar a multa em valor superior ao da obrigação.

Há diversos precedentes do STJ assentando ser possível a redução das astreintes já incididas e fixadas fora dos parâmetros de razoabilidade e proporcionalidade, para fixá-las ao valor da obrigação e evitar o "enriquecimento ilícito" do autor, citando-se como exemplos o AgRg no AREsp 429493-RJ, julgado pela quarta turma do STJ em 24/06/2014 e o AgRg no REsp 1461298-SP, julgado pela terceira turma do STJ em 17/03/2015 ${ }^{14}$.

Deve-se repelir o argumento de que o valor elevado da multa geraria o enriquecimento sem causa do consumidor, porquanto haveria causa legítima para esse acréscimo patrimonial: a resistência imotivada do fornecedor em se submeter ao comando judicial, não podendo se locupletar da própria torpeza, vindo a ser agraciado com a redução do valor da multa a um patamar irrisório, o que geraria o efeito multiplicador da inadimplência e da contumácia dos fornecedores em geral.

A partir de uma premissa equivocada, porém fortalecida ao longo dos anos em torno do alcance do revogado parágrafo $6^{\circ}$ do art. 461 do CPC/73, espraiou-se o entendimento quanto à possibilidade de redução das astreintes nas relações de consumo, mesmo após o trânsito em julgado da decisão, a pretexto de se corrigir desvios quanto ao seu valor, quando supostamente fora dos parâmetros de razoabilidade e proporcionalidade ou quando tenha se tornado exorbitante, limitando-se ao valor do benefício econômico pretendido com a ação.

Reconhecer as premissas acima como verdadeiras implicaria relegar o instituto da astreinte e a própria eficácia das tutelas executivas ao descrédito, gerando um efeito inverso no processo, para não dizer perverso, porquanto será estratégica e economicamente mais vantajoso para o réu protelar a satisfação do comando judicial, beneficiando-se da mora, para fomentar a elevação do valor da multa a um patamar que supere o benefício econômico da ação, para, após

\footnotetext{
${ }^{14} \mathrm{O}$ relator do recurso, João Otávio de Noronha, reconheceu a pertinência da decisão proferida pelo tribunal de origem a respeito da possibilidade de redução da multa, transcrevendo o seguinte trecho: "O Tribunal não modifica o que decidiu, lembrando que está autorizado a, de ofício, reduzir a multa cominatória quando ela for excessiva ou incompatível com a razoabilidade (art. $461, \S 5^{\circ}$, do CPC). Não é a multa instrumento de enriquecer o litigante que não cuida de requerer, oportunamente, a devida provocação para que a outra parte retire o nome do SERASA. Para a Turma Julgadora o valor da penalidade não poderia superar o quantum estabelecido para compensar o dano decorrente da inscrição indevida e essa conclusão é definitiva”.
} 


\section{A REGULAÇÃO DAS ASTREINTES NO CÓDIGO DE PROCESSO CIVIL E NO CÓDIGO DE DEFESA \\ DO CONSUMIDOR: EFEITOS SOBRE A EFICÁCIA DAS AÇÕES PARA A TUTELA DAS \\ OBRIGAÇÕES ESPECÍFICAS EM DEMANDAS DE CONSUMO}

anos de resistência injustificada, usar o pueril argumento de que a multa ficou excessivamente elevada e, para evitar o enriquecimento "sem causa" do consumidor, impugnar sua execução e pleitear sua redução em juízo.

Neste particular, não havia que se falar em diálogo de fontes entre o CPC e o CDC, na medida em que aquele malsinado parágrafo $6^{\circ}$ do artigo 461 não conversava e sim contradizia toda a lógica da execução indireta da obrigação específica do art. 84 do CDC, como consectária natural da multa, motivo pelo qual a redução do seu valor inequivocamente compromete a sua força psicológica e dissuasória. Tal consequência é nefasta para o mercado de consumo, premiando a desobediência e a insurgência ilegítima do fornecedor sob a chancela do Judiciário.

Em que pese o STJ tenha fixado o entendimento de que a astreinte não transita em julgado e, portanto, poderia ser reduzida ou até mesmo revogada a qualquer tempo ${ }^{15}$, o art. 537 do atual Código de Processo Civil ao estabelecer que "o juiz poderá, de ofício ou a requerimento, modificar o valor ou a periodicidade da multa vincenda ou exclui-la"16, parece deixar claro e insuscetível de dúvidas não mais ser possível alterar a multa já vencida.

Logo, qualquer alteração quanto ao valor e à periodicidade da multa deve projetar efeitos apenas para o futuro, permanecendo hígido o montante acumulado a partir das circunstâncias consolidadas no passado, este é o entendimento mais alinhado ao escopo protetivo do Código de Defesa do Consumidor sobre o consumidor em meio aos abusos experimentados nas relações de consumo e que não raro seguem para a relação processual.

Ocorre que a quarta turma do STJ, em julgamento proferido em 17/11/16 ${ }^{17}$, definiu parâmetros para a fixação das astreintes de modo não próximo à regulação do $\mathrm{CPC}$, possibilitando uma ampla margem de discricionariedade judicial. A turma seguiu o voto divergente do ministro Luís Felipe Salomão em caso que versava sobre multa no valor de R \$$1.000,00$ por dia de atraso, fixada em tutela antecipada, para que a instituição financeira baixasse o gravame do veículo da autora, o que só foi feito 407 dias depois.

\footnotetext{
${ }^{15}$ Alguns precedentes são encontrados em: REsp 1.019.455-MT, Terceira Turma, DJe 15/12/2011; AgRg no AREsp 408.030-RS, Quarta Turma, DJe 24/2/2014. REsp 1.333.988-SP, Rel. Min. Paulo de Tarso Sanseverino, julgado em 9/4/2014.

${ }^{16}$ Art. 537. A multa independe de requerimento da parte e poderá ser aplicada na fase de conhecimento, em tutela provisória ou na sentença, ou na fase de execução, desde que seja suficiente e compatível com a obrigação e que se determine prazo razoável para cumprimento do preceito. $\S 1$ o O juiz poderá, de ofício ou a requerimento, modificar o valor ou a periodicidade da multa vincenda ou excluí-la, caso verifique que: I - se tornou insuficiente ou excessiva; II - o obrigado demonstrou cumprimento parcial superveniente da obrigação ou justa causa para o descumprimento.

${ }^{17}$ A decisão foi proferida em sede de AgInt no AgRg no Agravo em Recurso Especial no 738.682 - RJ (2015/0162885-3). Rel. Min. Maria Isabel Gallotti.
} 
Ao apresentar o voto vista, o ministro chamou a atenção para a dispersão doutrinária a respeito de critérios à fixação do valor das astreintes, ressaltando que ora sobressai o valor "efetividade da tutela judicial", ora sobressai a "vedação ao enriquecimento sem causa", a primeira por vezes resultando em valores elevadíssimos e a segunda em valores irrisórios.

Buscando congregar os diferentes critérios adotados pelas turmas do STJ, estipulou-se que, dependendo das circunstâncias do caso concreto, devem ser observados para verificar a manutenção, ou não, do montante total acumulado a título de multa: 1) o valor da obrigação e importância do bem jurídico tutelado; 2) o tempo para cumprimento (prazo razoável e periodicidade); 3) a capacidade econômica e capacidade de resistência do devedor, e 4) a possibilidade de adoção de outros meios pelo juiz e o dever do credor de mitigar o próprio prejuízo (duty to mitigate de loss).

Ao fim, o ministro Salomão concluiu que o valor acima de R\$-400.000,00 fugia à razoabilidade, eis que a obrigação principal era de $\mathrm{R} \$ 110.000,00$, reduzindo em seguida a multa para $\mathrm{R} \$-100.000,00$. Com voto parcialmente vencido, a relatora Isabel Galloti reconheceu o acerto de tais critérios, apenas chegando a resultado diverso.

Resta ainda saber se o montante da multa deve ser considerado para fins de adequação do rito adotado nos Juizados Especiais Cíveis no âmbito da Justiça Estadual e Federal, instituídos pela Lei 9.099/95 e Lei 10.259/01, respectivamente. Ou seja, se o juiz deve observar o teto daqueles procedimentos aquando da fixação da multa, de 40 e 60 salários-mínimos respectivamente.

Inicialmente, a jurisprudência considerava que a fixação do valor da multa pelo juiz deveria se ater aos limites de alçada no procedimento dos Juizados Especiais (AMARAL, 2010, p. 180). Posteriormente, atentos ao fato de que a multa deve dispor de força suficiente para alcançar a efetividade das decisões judiciais, jurisprudência e doutrina pacificaram o entendimento de que as astreintes não devem observar os limites de alçada dos Juizados Especiais, não havendo de se cogitar em modificação de competência dos Juizados Especiais para a execução do julgado ${ }^{18}$.

\footnotetext{
${ }^{18} \mathrm{O}$ fato é que qualquer tentativa de se estipular um "teto" restaria prejudicada nos casos envolvendo direitos não patrimoniais ou de direitos que dificilmente poderiam ser reduzidos a pecúnia (MARINONI, 2012).
} 
5 CARACTERIZAÇÃO DA MORA NO CUMPRIMENTO DA OBRIGAÇÃO E TERMO INICIAL DA COBRANÇA DA MULTA

O devedor, em muitas ocasiões, sustenta que inexiste mora, porquanto não teria sido intimado pessoalmente da decisão concessiva da tutela específica, bem como sustenta a aplicação da teoria do dever de mitigar o próprio prejuízo (duty to mitigate the loss).

Os argumentos acima não podem prosperar, haja vista que o termo inicial do prazo conferido na decisão para o cumprimento da obrigação se inicia com a intimação do réu, pelos meios regulares de comunicação dos atos processuais, independentemente da pessoalidade do ato. A intimação por Diário da Justiça tem sido consolidada como a principal via de comunicação processual no Brasil, nos termos do inciso I do art. 513 do CPC/15, razão pela qual se o réu não cumprir a ordem judicial, assumirá o risco de sua desídia, não podendo lançar mão deste argumento como escusa ao cumprimento da obrigação.

A justificativa comumente alegada para obstar o cumprimento da obrigação e, por conseguinte, o pagamento da multa, refere-se a uma suposta obrigação do credor de requerer, a despeito de já efetivada a intimação do devedor, a reiteração da ordem judicial, com espeque na teoria do dever de mitigar o próprio prejuízo, aduzindo ser necessária nova intimação, desta vez para comunicar o prazo a partir do qual passará a incidir a multa.

Neste particular, caberia ao devedor que suscitar a teoria da mitigação do prejuízo ter em consideração o instituto da litigância de má-fé, consubstanciado, muitas vezes, na recusa injustificada à obediência de uma ordem judicial, a qual pode resultar na cominação, além das sanções criminais, civis e processuais cabíveis, de multa de até vinte por cento do valor da causa $^{19}$, sem prejuízo da cobrança da multa coercitiva objeto desta pesquisa.

É comum os fornecedores esquivarem-se ao pagamento da multa sob a alegação de ausência de intimação pessoal do devedor. O CPC/73 não tratava sobre a forma de intimação para a incidência da multa, o que fez surgir na doutrina e jurisprudência duas posições distintas: a primeira exigia a intimação pessoal e a outra tinha por suficiente a intimação na pessoa do

\footnotetext{
${ }^{19}$ Art. 77. Além de outros previstos neste Código, são deveres das partes, de seus procuradores e de todos aqueles que de qualquer forma participem do processo: (...) IV - cumprir com exatidão as decisões jurisdicionais, de natureza provisória ou final, e não criar embaraços à sua efetivação (...); § 2으 A violação ao disposto nos incisos IV e VI constitui ato atentatório à dignidade da justiça, devendo o juiz, sem prejuízo das sanções criminais, civis e processuais cabíveis, aplicar ao responsável multa de até vinte por cento do valor da causa, de acordo com a gravidade da conduta. § $4^{\circ} \mathrm{A}$ multa estabelecida no $\S 2^{\circ}$ poderá ser fixada independentemente da incidência das previstas nos arts. $523, \S 1^{\circ}$, e $536, \S 1^{\circ}$.
} 
advogado. Foi neste contexto que o STJ, em 2009, aprovou a Súmula 410, dispondo que: "a prévia intimação pessoal do devedor constitui condição necessária para a cobrança de multa pelo descumprimento de obrigação de fazer ou não fazer".

Com base no fato de se tratar de atos que dependiam da atuação pessoal da parte e em razão do ônus financeiro que poderia advir com o descumprimento da decisão, a Súmula 410 conquistou renomados adeptos ${ }^{20}$. No entanto, o valor da efetividade processual fortaleceu a presunção de comunicação dos atos ocorridos no processo, inerente à relação advogado-cliente. Ainda, se com base no art. 475-J do CPC/73 admitia-se a possibilidade de o advogado ser intimado em nome da parte para pagamento da condenação em quantia certa, inexistiam razões para não se admitir a intimação do advogado em nome da parte para o cumprimento da obrigação específica garantida pela multa.

A corrente que defende a suficiência da intimação do advogado ganhou relevância no julgamento dos Embargos de Divergência EAg 857.758/RS, de relatoria da ministra Nancy Andrighi, publicado em 25/08/2011. Na ocasião, a ministra ressaltou que não há distinção ontológica entre ato de fazer e de pagar e chamou a atenção para a necessidade de uniformizar os procedimentos, evitando "arapucas" processuais que dificultam a atuação em juízo e aumentam a insegurança jurídica.

Mesmo após a formal pacificação da questão com o julgamento dos Embargos de Divergência supracitados nos moldes propostos pela ministra Nancy Andrighi, e o afastamento da Súmula 410, juízes e Tribunais permanecem adotando os dois entendimentos distintos. Aliás, a controvérsia permanece entre as turmas do STJ. Na relatoria de novos Embargos de Divergência em REsp 1.360.557/MG, publicado em 11/02/2016, o ministro Humberto Martins alegou ser tema pacífico na Corte a desnecessidade da intimação pessoal para a cobrança da multa. Na ocasião, o ministro Luís Felipe Salomão apresentou voto-vista divergindo do relator.

No voto-vista, o ministro Salomão consignou que as multas viram condenações astronômicas por ausência de conhecimento do próprio devedor acerca da obrigação, agravado pelo emaranhado burocrático de uma grande corporação empresarial. Para o ministro "são essas multas, de caráter milionário, que levam ao descrédito onde se é necessário fazer cumprir obrigação de fazer”. Ressaltou, ainda, a higidez da Súmula 410 e a permanecia desta orientação na seção de direito privado, concluindo que o CPC/15 teria resolvido a questão a favor da intimação pessoal do devedor.

${ }^{20}$ Cite-se juristas como Guilherme Rizzo Amaral e Candido Dinamarco. 
Em que pese a omissão do CPC/15 sobre a forma de intimação para a exigibilidade da multa coercitiva, a controvérsia não merece prosperar em razão do que dispõe o $\S 2^{\circ}$ do art. 513, situado nas disposições gerais para o cumprimento de sentença, segundo o qual o devedor será intimado para cumprir a sentença pelo Diário da Justiça, na pessoa de seu advogado constituído nos autos.

Por fim, cabe mencionar que determinados juízes preferem não aplicar a multa num primeiro momento, a despeito de requerimento expresso do consumidor neste sentido, optando apenas por advertir o devedor de que, no caso de inadimplência da obrigação, incidirá a penalidade por ato atentatório à dignidade da justiça. Tal possibilidade deveria funcionar como segunda opção do magistrado, jamais como a primeira, pois cria um prazo adicional ao devedor antes da aplicação da multa, fomentando o seu descumprimento. Este estágio adicional, como condição prévia para a aplicação da multa, desvirtua o próprio instituto.

\section{MOMENTO ADEQUADO PARA A EXECUÇÃO DA MULTA APLICADA EM SEDE DE TUTELA PROVISÓRIA}

O posicionamento quanto ao momento para a exigibilidade, ou cobrança, da multa coercitiva fixada em sede de tutela provisória (se antes ou depois do trânsito em julgado da sentença de procedência) depende da natureza jurídica que se confere à multa, conforme discorrido em tópico anterior. Esta controvérsia resultou em uma das mais acirradas polêmicas em torno da aplicação das astreintes, fomentada pela insuficiência de regulação do tema no Código de 1973.

Para os que defendem a natureza de preservação da autoridade judicial, o fato gerador da incidência e exigibilidade da multa seria o descumprimento da decisão provisória, como forma de incutir nos jurisdicionados o sentimento de que as decisões judiciais presumem-se verossímeis e são cumpridas, aumentando a confiança na justiça e o prestígio do Poder Judiciário. O réu seria coagido a cumprir o comando judicial pelo receio em ser punido através da execução da multa. A medida, então, não teria qualquer relação com o direito material declarado na decisão e serviria prioritariamente para manter a higidez da relação Estado-parte.

Em um contexto marcado pelo descumprimento corriqueiro das ordens judiciais, enfraquecendo a confiança que se espera nos órgãos judiciais, é natural que este posicionamento atraia adeptos e surja como uma solução louvável ao combatido problema da resistência ao 
cumprimento dos provimentos judiciais. Entretanto, considerando o real propósito da multa, o seu enquadramento no artigo 537 do CPC/15 como instrumento ligado à satisfação específica do direito material bem como a melhor construção doutrinária sobre o tema, parece evidente que a multa assume caráter estritamente coercitivo e acessório em relação ao direito material.

Portanto, exclui-se a possibilidade de execução definitiva da multa cominada em tutela provisória antes do trânsito em julgado da sentença, posto que esta solução apenas é compatível com o entendimento que atribui caráter punitivo à medida, além de que, esta solução poderia ensejar uma "indústria de multas", na medida em que o autor ingressaria com a ação e empenhar-se-ia bem mais em demonstrar o inadimplemento da decisão provisória do que propriamente o direito alegado.

Por outro lado, aguardar o trânsito em julgado da sentença de procedência para iniciar a execução da multa tende a desprestigiar os provimentos provisórios pautados pela urgência em se conferir proteção adequada, tempestiva e efetiva aos direitos ameaçados de perecimento pela natural duração processual, justificando uma proteção mais efetiva, donde a exigibilidade imediata da multa para reforçar a satisfação daqueles direitos seria medida imperiosa.

Não há como negar, todavia, que a cognição em tutela provisória é sumária e, por isso, passível de modificação, razão pela qual o procedimento para o cumprimento provisório da sentença disciplinado no artigo 520 do $\mathrm{CPC} / 15^{21}$, o qual autoriza o início regular da execução, porém com algumas limitações, revela-se o mais adequado.

Conclui-se que o novo diploma processual decidiu bem a questão ao dispor, no $\S 3^{\circ}$ do art. 537, que a decisão veiculadora da multa é passível de cumprimento provisório, devendo ser depositado em juízo o valor acumulado desde o dia em que se configurou o descumprimento até o efetivo cumprimento da decisão, permitindo o levantamento do montante após o trânsito em julgado da sentença favorável à parte ou na pendência do agravo fundado nos incisos II ou III do art. 1.042. Ainda que não cumprida a decisão, é possível o depósito do valor da multa acumulado até então.

\footnotetext{
${ }^{21} \mathrm{O}$ procedimento para o cumprimento provisório da sentença que reconhece a exigibilidade de obrigação de pagar quantia certa disciplinado nos artigos 520-522 do CPC/15 aplica-se às decisões concessivas de tutela provisória e que reconhecem obrigação de fazer, não fazer ou de dar coisa, com fulcro no art. 519 e no $\S 4^{\circ}$ do art. 520 .
} 


\section{A CONVERSÃO DA MULTA EM PERDAS E DANOS}

O art. 84, em seu $\S 1^{\circ}$, traz a possibilidade de conversão da obrigação específica em perdas e danos em duas hipóteses: opção expressa do consumidor e impossibilidade (lógica, técnica ou jurídica) de cumprimento da tutela, o que deverá ser provado de maneira inconteste.

Desse modo, exige-se robusta comprovação técnica da impossibilidade de cumprimento da obrigação, o que, preferencialmente, deverá ocorrer logo no primeiro momento em que o fornecedor tiver a oportunidade de falar nos autos, seja como forma de minimizar o impacto negativo da demora ou impossibilidade de cumprimento da tutela específica, seja para afastar a exigibilidade da multa fixada como medida dissuasória, juntamente com a ordem judicial. Na prática, essa proatividade acabará, também, por preservar os interesses do réu de boa-fé que, efetivamente impossibilitado de cumprir a decisão, venha amargar um prejuízo financeiro e processual irreversível com o transcurso in albis do prazo de cumprimento, sem apresentar uma legítima escusa.

A impossibilidade lógica, técnica ou jurídica de cumprimento da obrigação pelo réu deverá ser suscitada a partir de sua intimação, sendo estas as únicas recusas legítimas admitidas para suspender a exigibilidade da multa cominatória, cuja mora continuará a fluir se o devedor não demonstrar uma legítima objeção. Preza-se, neste caso, pela lealdade processual, bem como a prerrogativa do credor de optar pela conversão da obrigação em perdas e danos, apenas quando não for possível dar efetividade ao provimento cominatório.

Por fim, cabe consignar que o $\$ 2^{\circ}$ do art. 84 do CDC dispõe que a conversão da obrigação em perdas e danos se dará sem prejuízo da multa fixada.

\section{CONSIDERAÇÕES FINAIS}

Ao longo da pesquisa foi possível observar a importância da multa coercitiva ao atingimento dos escopos da Jurisdição no Estado Contemporâneo e da realização do direito material pela via processual sincrética. Observou-se que, não obstante a importância ímpar de sua aplicação para o cumprimento das obrigações de fazer, não fazer, entregar coisa e de pagar quantia, as divergências doutrinárias e jurisprudenciais criadas em torno das lacunas do diploma processual anterior contribuíram, a um só tempo, para o aumento da insegurança jurídica e da perda do potencial coercitivo da medida, culminando no descrédito da atividade jurisdicional. 
Embora ainda não se verifiquem estudos teóricos mais profundados em torno da regulação da multa pelo recém-publicado Código de Processo Civil, a partir da análise dos estudos realizados sob a égide do Código anterior em cotejo com a nova disciplina é possível concluir pelo avanço do sistema de tutela específica das obrigações, em benefício especialmente do consumidor. Agora, pode-se estender, com maior segurança, a aplicação da multa para assegurar o cumprimento da obrigação de pagar quantia e como medida de reforço ao cumprimento da medida cautelar de exibição de documento.

No que tange à titularidade do crédito advindo da multa, o Código encerrou as discussões de que o Estado deveria ser seu titular ao dispor, expressamente, ser o valor da multa devido ao exequente. Pensamos que o posicionamento mais significativo e acertado do Código em relação às astreintes, contudo, foi disciplinar detalhadamente o modo e o momento de exigibilidade da multa quando aplicada em sede de tutela provisória de natureza satisfativa. Agora, ante a recalcitrância do devedor, é possível o cumprimento provisório, desde logo, da decisão que tenha fixado a multa, devendo o valor ser depositado em juízo, assegurando o seu levantamento após o trânsito em julgado da sentença favorável à parte. Posicionamento este compatível com a natureza jurídica de técnica processual da multa.

Pensamos, no entanto, que o legislador perdeu a oportunidade de encerrar a questão relativa à forma de intimação do réu para o cumprimento da obrigação, se na pessoa do próprio devedor ou de seu advogado, embora o melhor entendimento sob a perspectiva da efetividade, da duração razoável do processo e da lealdade processual, somados a uma interpretação sistemática do art. 513 do CPC, apontem pela suficiência da intimação via advogado.

Por fim, no que tange aos limites do valor da multa, pensamos que inexistem razões relevantes que o vincule ao valor do bem jurídico discutido, sob pena de considerável perda do seu potencial dissuasório, nem havendo de se cogitar em enriquecimento ilícito da parte adversa, tendo em vista que o fundamento de sua incidência é a resistência ao cumprimento da decisão, em prejuízo direto ao autor. Ainda, embora a redação do art. 537 do CPC aponte acertadamente para a impossibilidade de modificação do valor e da periodicidade da multa vincenda, permanece o entendimento, pelo Superior Tribunal de Justiça, da possibilidade de reduzir a multa já constituída no passado, o que poderá enfraquecer a medida coercitiva em casos futuros, na contramão dos avanços identificados no decorrer da pesquisa. 


\section{REFERÊNCIAS}

AMARAL, Guilherme Rizzo. As astreintes e o processo civil brasileiro. Multa do art.461 do CPC e outras. 2. ed. Porto Alegre: Livraria do Advogado, 2010.

ARENHART, Sérgio Cruz. A doutrina brasileira da multa coercitiva - três questões ainda polêmicas. São Paulo: Revista Forense, v. 104, n. 396, p. 233-255, mar/abr. 2008. Disponível em: http://ufpr.academia.edu/SergioCruzArenhart/Papers.

BUENO, Cassio Scarpinella. Novo código de processo civil anotado. São Paulo: Saraiva, 2015.

CARVALHO, Fabiano. Execução da multa (astreintes) prevista no art. 461 do CPC. Revista de Processo, São Paulo, n. 114, ano 29, p. 208-222, mar./abr. 2004.

GUERRA, Marcelo Lima. Execução indireta. São Paulo: Revista dos Tribunais, 1998.

SPADONI, Joaquim Felipe. A multa na atuação das ordens judiciais. In: SHIMURA, Sérgio e WAMBIER, Teresa Arruda Alvim (Coord.). Processo de execução e assuntos afins - v. 2. São Paulo: Revista dos Tribunais, 2001.

MARINONI, Luiz Guilherme. Técnica processual e tutela dos direitos. 3. ed. rev. e atual. São Paulo: Revista dos Tribunais, 2010.

2012.

Tutela inibitória: individual e coletiva. 5. ed. São Paulo: Revista dos Tribunais,

SPADONI, Joaquim Felipe. A multa na atuação das ordens judiciais. In: SHIMURA, Sérgio e WAMBIER, Teresa Arruda Alvim (Coord.). Processo de execução e assuntos afins - v. 2. São Paulo: Editora Revista dos Tribunais, 2001.

TALAMINI, Eduardo. Tutela relativa aos deveres de fazer e não fazer: e a sua extensão aos deveres de entregar coisa (CPC arts. 461 e 461-A, CDC, art. 84). 2. ed. São Paulo: Revista dos Tribunais, 2003.

Tutela relativa aos deveres de fazer e não fazer: CPC, art. 461; CDC, 84. São Paulo: Revista dos Tribunais, 2001

Revista de Direito, Globalização e Responsabilidade nas Relações de Consumo | e-ISSN: 2526-0030 | Maranhão | v. 3 | n. 2 | p. $82-102$ | Jul/Dez. 2017 